STUDIA I PRACE WYDZIAŁU NAUK EKONOMICZNYCH I ZARZĄDZANIA nr 41, t. 2

\title{
Damian Dunajko*
}

Izabela Klepacka-Dunajko**

Uniwersytet Przyrodniczo-Humanistyczny w Siedlcach

\section{PRZESTRZENNE ZRÓŻNICOWANIE WARTOŚCI WSKAŹNIKA PRZEDSIĘBIORCZOŚCI WOJEWÓDZTWA ŚLĄSKIEGO}

\begin{abstract}
Streszczenie
W artykule przedstawiono wyniki badań dotyczące związku pomiędzy wartością wskaźnika przedsiębiorczości gmin wiejskich i miejsko-wiejskich województwa śląskiego a odległością tych gmin od ośrodków gospodarczych. Przyjęto, że głównymi ośrodkami gospodarczymi województwa śląskiego są miasta powiatowe: Będzin, Bielsko-Biała, Bieruń, Cieszyn, Częstochowa, Gliwice, Kłobuck, Lubliniec, Mikołów, Myszków, Pszczyna, Racibórz, Rybnik, Tarnowskie Góry, Wodzisław Śląski, Zawiercie, Żywiec. Wskaźnik przedsiębiorczości został określony jako liczba podmiotów gospodarczych zarejestrowanych w systemie REGON w przeliczeniu na 10 tys. ludności w wieku produkcyjnym. Odległości gmin wiejskich od ośrodków gospodarczych zostały wyrażone jako najkrótsze odległości drogowe. Stwierdzono, że występuje statystyczna zależność między wartością wskaźnika przedsiębiorczości w gminie wiejskiej a jej odległością od ośrodka gospodarczego.
\end{abstract}

Słowa kluczowe: obszary wiejskie, przedsiębiorczość, odległość, wskaźnik przedsiębiorczości, układ przestrzenny, województwo śląskie

* E-mail: damian.dunajko@gmail.com

** E-mail: Izabela.Klepacka@interia.pl 


\section{Wprowadzenie}

W ciągu wielu lat można spostrzec pogłębiające się zmiany na polskiej wsi. Wpływ ma na to wiele czynników ekonomicznych, m.in. trudności związane ze sprzedażą produktów rolniczych wynikające z konfliktów politycznych. Obliguje to do obniżenia cen produktów rolniczych na rynku. Rolnicy zmuszeni są do dywersyfikacji działalności rolniczej. Według Lecha Pałasza rozwój społeczno-gospodarczy w poszczególnych gminach następuje w różnym tempie i określonych kierunkach. Zależy to m.in. od zgromadzonych funduszy, położenia względem dużych miast, szlaków komunikacyjnych, poziomu rozwoju i struktury gospodarki ${ }^{1}$.

Działalność rolnicza jako jedyne źródło utrzymania nie zawsze przynosi zadowalające dochody. Zgodnie z koncepcją rozwoju wielofunkcyjnego wsi wskazane byłoby łączenie ze sobą innych rodzajów działalności gospodarczej. Proces ten jest wyrazem przedsiębiorczości społeczności wiejskiej, w której wyniku pojawiają się dodatkowe źródła dochodów i nowych miejsc pracy na terenach wiejskich.

Skuteczność przedsiębiorczych inicjatyw, ich natężenie i zasięg zależą nie tylko od samych przedsiębiorców, lecz także od charakteru otoczenia, systemu gospodarczego, w jakim przychodzi im działać. Mamy tu do czynienia z określonymi regulacjami prawnymi, które są bardziej lub mniej sprzyjające przedsiębiorczości, określoną infrastrukturą finansową (banki, rynek kapitałowy), a także infrastrukturą techniczną (telekomunikacja, transport, sieć hoteli). Ważnym elementem otoczenia jest poziom systemu edukacyjnego, a także odpowiednie zrozumienie i zainteresowanie ze strony polityków ${ }^{2}$. W rozwoju przedsiębiorczości istotne są zarówno indywidualne cechy osobowości, kompetencje czy doświadczenie, jak i makrootoczenie. Strategia rozwoju gminy, aktywna postawa władz lokalnych jest jednym z głównych czynników społeczno-gospodarczych wpływających na poziom rozwoju przedsiębiorczości na terenie gminy.

Województwo śląskie leży w południowej części kraju. Obejmuje obszar $12333,09 \mathrm{~km}^{2}$ i jest zamieszkiwane przez 4,59 mln mieszkańców, co stanowi 11,9\% ogółu ludności, w tym teren wiejski zamieszkuje 26,7\% ludzi. Sieć osadniczą województwa tworzy 17 powiatów ziemskich i 19 powiatów grodzkich, które dzielą się na 49 gmin miejskich, 22 gminy wiejsko-miejskie i 96 wiejskich ${ }^{3}$.

L. Pałasz, Aktywność samorządów gmin w rozwoju obszarów wiejskich, Materiały VI Kongresu SERiA, z. 1. Rzeszów 1999, s. 483-490.

2 J. Schumpeter, Teoria rozwoju gospodarczego, PWN, Warszawa 1960, s. 36.

3 http:/www.stat.gov.pl/, GUS 2013 [dostęp 12.09.2015]. 
Celem niniejszego artykułu jest przedstawienie stanu rozwoju przedsiębiorczości obszarów województwa śląskiego oraz wskazanie związku między wartością wskaźnika przedsiębiorczości a odległością jednostek przestrzennych od ośrodków gospodarczych.

\section{Metody opracowania}

W pracy przedstawiono wyniki badań dotyczących zależności pomiędzy wartością wskaźnika przedsiębiorczości na obszarach wiejskich województwa śląskiego a odległością jednostek przestrzennych (gmin wiejskich) od ośrodków gospodarczych.

Wskaźnik przedsiębiorczości wyrażono liczbą podmiotów gospodarczych zarejestrowanych w systemie REGON w przeliczeniu na 10000 mieszkańców w wieku produkcyjnym. Wzór wyrażono za pomocą następującej formuły4:

gdzie:

$$
W p=\frac{P}{L} \times 10000
$$

$W p$ - wskaźnik przedsiębiorczości;

$P$ - liczba zarejestrowanych podmiotów gospodarczych;

$L$ - liczba ludności w wieku produkcyjnym.

Odległości poszczególnych jednostek przestrzennych od ośrodków gospodarczych zostały określone jako najkrótsze odległości drogowe. Przyjęto, że ośrodkami gospodarczymi są miasta powiatowe dla gmin wchodzących w skład danego powiatu.

W celu określenia zależności pomiędzy wartością wskaźnika przedsiębiorczości a odległością od ośrodków gospodarczych przeprowadzono analizę korelacji.

Badanie przeprowadzono na podstawie danych dotyczących 96 gmin wiejskich i 22 gmin miejsko-wiejskich województwa śląskiego, pochodzących z Banku Danych Lokalnych Głównego Urzędu Statystycznego. W procedurze obliczania wskaźnika przedsiębiorczości wykorzystano dane statystyczne z 2013 roku (stan na 31 grudnia).

\footnotetext{
4 M. Iwańska, M. Bieńkowska, Zróżnicowanie wartości wskaźnika przedsiębiorczości w gminach wiejskich województwa mazowieckiego w układzie przestrzennym, Acta Scientiarum Polonorum. Oeconomia 9 (3), SGGW, Warszawa 2010, s. 120.
} 


\section{Wyniki badań}

Obliczono wskaźnik przedsiębiorczości dla wszystkich gmin wiejskich województwa śląskiego, jednostki poddano procedurze rangowania, szeregując je od gmin, w których wskaźnik osiągnął najwyższą wartość. W tabeli 1 przedstawiono 10 gmin o najwyższym wskaźniku przedsiębiorczości oraz 10 gmin, w których wskaźnik był najniższy.

Najwyższymi wartościami wskaźnika przedsiębiorczości charakteryzują się gminy powiatu bielskiego, pszczyńskiego i tarnogórskiego, a najniższe wartości występują w powiecie raciborskim (tabela 1). Najwyższy wskaźnik przedsiębiorczości (w gminie Jaworze) prawie czterokrotnie przewyższa wskaźnik przedsiębiorczości w gminie Krzanowice.

Tabela 1. Wartość wskaźnika przedsiębiorczości oraz odległości jednostek terytorialnych od ośrodków gospodarczych w 2013 roku

\begin{tabular}{|l|l|l|c|c|}
\hline Lp. & \multicolumn{1}{|c|}{ Gmina } & \multicolumn{1}{|c|}{ Powiat } & $\begin{array}{c}\text { Wskaźnik } \\
\text { przedsiębiorczości }\end{array}$ & $\begin{array}{c}\text { Odległość od ośrodka } \\
\text { gospodarczego (km) }\end{array}$ \\
\hline 1 & Jaworze & bielski & 2494,9 & 10,3 \\
\hline 2 & Pszczyna & pszczyński & 1941,2 & 0,0 \\
\hline 3 & Goczałkowice-Zdrój & pszczyński & 1940,5 & 5,6 \\
\hline 4 & Wilkowice & bielski & 1911,5 & 10,5 \\
\hline 5 & Koziegłowy & myszkowski & 1834,8 & 12,7 \\
\hline 6 & Kozy & bielski & 1824,5 & 8,3 \\
\hline 7 & Świerklaniec & tarnogórski & 1822,1 & 7,6 \\
\hline 8 & Ożarowice & tarnogórski & 1807,7 & 16,8 \\
\hline 9 & Siewierz & będziński & 1726,4 & 20,1 \\
\hline 10 & Poraj & myszkowski & 1713,4 & 16,5 \\
\hline 11 & Łękawica & żywiecki & 881,0 & 8,4 \\
\hline 12 & Lubomia & wodzisławski & 878,3 & 13,9 \\
\hline 13 & Pietrowice Wielkie & raciborski & 871,6 & 9,1 \\
\hline 14 & Woźniki & lubliniecki & 859,0 & 30,8 \\
\hline 15 & Kłomnice & częstochowski & 857,7 & 21,3 \\
\hline 16 & Pawonków & lubliniecki & 846,7 & 8,4 \\
\hline 17 & Nędza & raciborski & 820,4 & 12,3 \\
\hline 18 & Irządze & zawierciański & 791,4 & 29,7 \\
\hline 19 & Kruszyna & częstochowski & 688,0 & 21,9 \\
\hline 20 & Krzanowice & raciborski & 683,0 & 12,4 \\
\hline & Zora & & \\
\hline
\end{tabular}

Źródło: obliczenia własne na podstawie danych Głównego Urzędu Statystycznego oraz www.mapa.pf.pl [dostęp 12.09.2015]. 
Średnia wartość wskaźnika przedsiębiorczości w badanych gminach wynosi 1258,7, a średnia odległość badanych jednostek od ośrodków przemysłowych $15,2 \mathrm{~km}$. Wartości te są zróżnicowane w poszczególnych powiatach województwa (tabela 2).

Tabela 2. Zróżnicowanie średniej wartości wskaźnika przedsiębiorczości oraz odległości w zależności od ośrodka gospodarczego w 2013 roku

\begin{tabular}{|l|l|c|c|}
\hline Lp. & \multicolumn{1}{|c|}{ Powiat } & $\begin{array}{c}\text { Średnia wartość wskaźnika } \\
\text { przedsiębiorczości }\end{array}$ & $\begin{array}{c}\text { Średnia odległość gmin od } \\
\text { ośrodka gospodarczego (km) }\end{array}$ \\
\hline 1 & bielski & 1657,3 & 12,3 \\
\hline 2 & myszkowski & 1628,2 & 13,3 \\
\hline 3 & będziński & 1573,4 & 16,4 \\
\hline 4 & tarnogórski & 1506,3 & 14,2 \\
\hline 5 & mikołowski & 1373,8 & 10,3 \\
\hline 6 & pszczyński & 1357,3 & 9,2 \\
\hline 7 & cieszyński & 1340,6 & 19,9 \\
\hline 8 & gliwicki & 1272,2 & 17,5 \\
\hline 9 & żywiecki & 1229,6 & 13,7 \\
\hline 10 & bieruńsko-łędziński & 1228,6 & 8,0 \\
\hline 11 & kłobucki & 1217,2 & 12,5 \\
\hline 12 & zawierciański & 1165,1 & 20,2 \\
\hline 13 & rybnicki & 1152,6 & 9,9 \\
\hline 14 & częstochowski & 1137,7 & 22,3 \\
\hline 15 & lubliniecki & 1042,1 & 17,1 \\
\hline 16 & wodzisławski & 1019,2 & 8,5 \\
\hline 17 & raciborski & 910,6 & 11,5 \\
\hline
\end{tabular}

Źródło: obliczenie własne.

Najwyższymi średnimi wartościami wskaźnika przedsiębiorczości charakteryzują się gminy wiejskie i miejsko-wiejskie położone w powiecie bielskim. Bielsko-Biała jest jednym z głównych ośrodkiem gospodarczych w województwie śląskim. Wysokim wskaźnikiem przedsiębiorczości charakteryzuje się również powiat myszkowski, który stanowi atrakcyjny pod względem turystycznym obszar województwa śląskiego. Najkrótszymi średnimi odległościami badanych jednostek terytorialnych od głównych ośrodków gospodarczych charakteryzują się gminy z powiatu bieruńsko-lędzińskiego i wodzisławskiego. 
Obliczono wskaźnik przedsiębiorczości dla wszystkich gmin wiejskich województwa śląskiego, dzięki czemu można było przyporządkować do odpowiednich klas (tabela 3), wyróżnionych na jego podstawie:

klasa 1 - wysoki poziom przedsiębiorczości,

klasa 2 - średni poziom przedsiębiorczości,

klasa 3 - niski poziom przedsiębiorczości,

klasa 4 - bardzo niski poziom przedsiębiorczości.

Dla wyznaczenia klas przyjęto za kryterium średnią wartość wskaźnika przedsiębiorczości $=1258,7$ oraz odchylenie standardowe $=306,4$.

Tabela 3. Klasy gmin ze względu na wartość wskaźnika przedsiębiorczości

\begin{tabular}{|l|c|c|c|}
\hline \multicolumn{1}{|c|}{ Klasa gmin } & Kryterium & $\begin{array}{c}\text { Przedział } \\
\text { liczbowy }\end{array}$ & $\begin{array}{c}\text { Liczebność } \\
\text { klasy }\end{array}$ \\
\hline $\begin{array}{l}\text { Klasa 1 - wysoki wskaźnik } \\
\text { przedsiębiorczości }\end{array}$ & $\max \mathrm{W}_{\mathrm{p}} ; \overline{\mathrm{W}}_{\mathrm{p}}+\mathrm{s}_{\mathrm{wp}}$ & $<1689 ; 1129>$ & 21 \\
\hline Klasa 2 - średni wskaźnik przedsiębiorczości & $\overline{\mathrm{W}}_{\mathrm{p}}+\mathrm{s}_{\mathrm{wp}} ; \overline{\mathrm{W}}_{\mathrm{p}}$ & $(1129 ; 874>$ & 33 \\
\hline Klasa 3 - niski wskaźnik przedsiębiorczości & $\overline{\mathrm{W}}_{\mathrm{p}} ; \overline{\mathrm{W}}_{\mathrm{p}}-\mathrm{s}_{\mathrm{wp}}$ & $(874 ; 618>$ & 49 \\
\hline $\begin{array}{l}\text { Klasa 4 - bardzo niski wskaźnik } \\
\text { przedsiębiorczości }\end{array}$ & $\overline{\mathrm{W}}_{\mathrm{p}}-\mathrm{s}_{\mathrm{wp}} ; \min \mathrm{W}_{\mathrm{p}}$ & $(618 ; 480>$ & 15 \\
\hline
\end{tabular}

Źródło: obliczenia własne.

Z tabeli 3 wynika, że najwięcej gmin wiejskich i miejsko-wiejskich województwa śląskiego należy do klasy 3, czyli o niskim poziomie przedsiębiorczości. Najmniej liczną grupą są gminy o bardzo niskim wskaźniku przedsiębiorczości, czyli klasa 4, w której znajduje się 15 jednostek. Na rysunku 1 można zauważyć występowanie jednostek o wysokim wskaźniku przedsiębiorczości wokół ośrodków gospodarczych - 45,8\% gmin mieści się w klasie o wysokim i średnim wskaźniku przedsiębiorczości, co świadczy o dużym zróżnicowaniu gmin.

Gminy wiejskie i miejsko-wiejskie województwa śląskiego w 54,2\% należą do klas o niskim i bardzo niskim poziomie przedsiębiorczości, w znaczącej części znajdują się najdalej od ośrodka gospodarczego. Wyjątkiem są powiaty o najmniejszych wskaźnikach przedsiębiorczości: raciborski i wodzisławski (rysunek 1), które są wysunięte najdalej na zachód ze wszystkich powiatów w województwie śląskim, wszystkie gminy plasują się w klasie 3 i 4. Może to być spowodowane różnymi czynnikami. Kluczowym warunkiem rozwoju lokalnego jest rozwój przedsiębiorczości. Na ten element zwraca uwagę również rządowa strategia gospodarcza pt. Przedsiębiorczość - rozwój - praca, w której zostało 
przyjęte m.in. założenie, że podstawowym czynnikiem wzrostu gospodarczego jest pobudzenie aktywności i przedsiębiorczości ${ }^{5}$. Zadaniem organów publicznych powinno być także występowanie w roli aktywnego kreatora rozwoju gospodarki lokalnej. Szansy ożywienia gospodarki należy szukać w opracowanych planach strategicznych gminy lub rejonu, tzn. kilku gmin, które powinny uwzględniać wielofunkcyjny rozwój tych terenów.

Odległość od ośrodka gospodarczego jest istotnym czynnikiem determinującym poziom przedsiębiorczości. Można zauważyć zależność między tymi dwiema zmiennymi. Dla weryfikacji tej hipotezy przeprowadzono analizę korelacji.

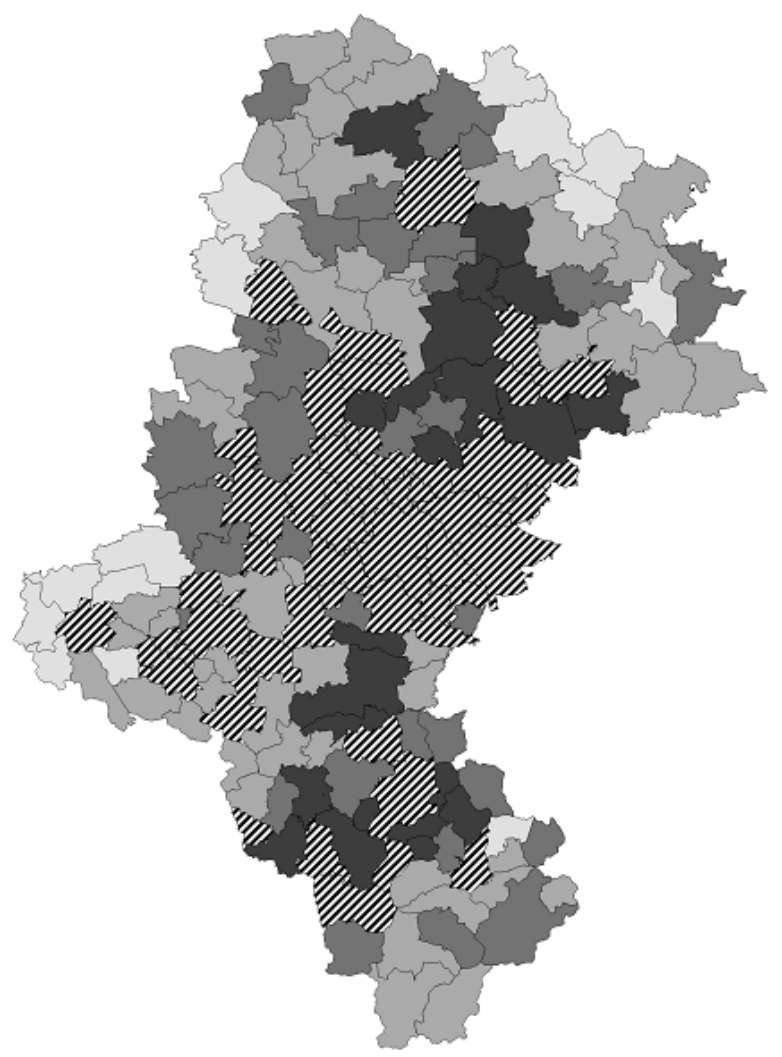

Rysunek 1. Przestrzenne rozmieszczenie jednostek terytorialnych w zależności od poziomu przedsiębiorczości

5 Rada Ministrów, Przedsiębiorczość - rozwój-praca. Strategia gospodarcza rządu, Warszawa, 2002, s. 6-7. 
Tabela 4. Liczba gmin w poszczególnych klasach

w zależności od najbliższego ośrodka gospodarczego

\begin{tabular}{|r|l|c|c|c|c|}
\hline Lp. Powiat & (iczba gmin & $\begin{array}{c}\text { Liczba gmin } \\
\text { w klasie 1 }\end{array}$ & $\begin{array}{c}\text { Liczba gmin } \\
\text { w klasie 3 }\end{array}$ & $\begin{array}{c}\text { Liczba gmin } \\
\text { w klasie 4 }\end{array}$ \\
\hline 1 & będziński & 2 & 2 & 0 & 0 \\
\hline 2 & bielski & 4 & 4 & 1 & 0 \\
\hline 3 & bieruńsko-łędziński & 0 & 1 & 1 & 0 \\
\hline 4 & cieszyński & 3 & 3 & 3 & 0 \\
\hline 5 & częstochowski & 1 & 6 & 5 & 4 \\
\hline 6 & gliwicki & 0 & 5 & 1 & 0 \\
\hline 7 & kłobucki & 1 & 1 & 7 & 0 \\
\hline 8 & lubliniecki & 0 & 1 & 3 & 3 \\
\hline 9 & mikołowski & 0 & 1 & 1 & 0 \\
\hline 10 & myszkowski & 3 & 1 & 0 & 0 \\
\hline 11 & pszczyński & 2 & 0 & 4 & 0 \\
\hline 12 & raciborski & 0 & 0 & 2 & 5 \\
\hline 13 & rybnicki & 0 & 1 & 4 & 0 \\
\hline 14 & tarnogórski & 2 & 3 & 0 & 0 \\
\hline 15 & wodzisławski & 0 & 0 & 4 & 1 \\
\hline 16 & zawierciański & 2 & 0 & 5 & 1 \\
\hline 17 & żywiecki & 1 & 4 & 8 & 1 \\
\hline
\end{tabular}

Źródło: obliczenia własne.

Miernikiem siły związku prostoliniowego między dwoma cechami mierzalnymi jest współczynnik korelacji liniowej Pearsona ${ }^{6}$, który oblicza się na podstawie następującego wzoru:

$$
r=\frac{\operatorname{cov}(x, y)}{s(x) s(y)}
$$

gdzie:

$r$ - współczynnik korelacji;

$\operatorname{cov}(x, y)$ - iloraz kowariancji zmiennych x i y;

$s(x) s(y)$ - iloczyn odchyleń zmiennych $\mathrm{x}$ i $\mathrm{y}$.

Wartość współczynnika korelacji mieści się w przedziale domkniętym $[-1,1]$. Im większa wartość bezwzględna współczynnika, tym silniejsza jest zależność liniowa między dwoma zmiennymi. Współczynnik $r=0$ oznacza brak liniowej zależności między zmiennymi, $\mathrm{r}=1$ oznacza dokładną liniową zależność między badanymi cechami. Współczynnik $r=-1$ oznacza ujemną liniową zależność między zmiennymi. Oznacza to, że jeżeli zmienna x rośnie, to zmienna y maleje

6 W. Oktaba, Elementy statystyki matematycznej o metodyka doświadczalnictwa, Wydawnictwo Akademii Rolniczej w Lublinie, Lublin 1980. 
i na odwrót ${ }^{7}$. Relacje między odległością od ośrodka gospodarczego (zmienna x) a poziomem przedsiębiorczości (zmienna y) przedstawiono na rysunku 2.

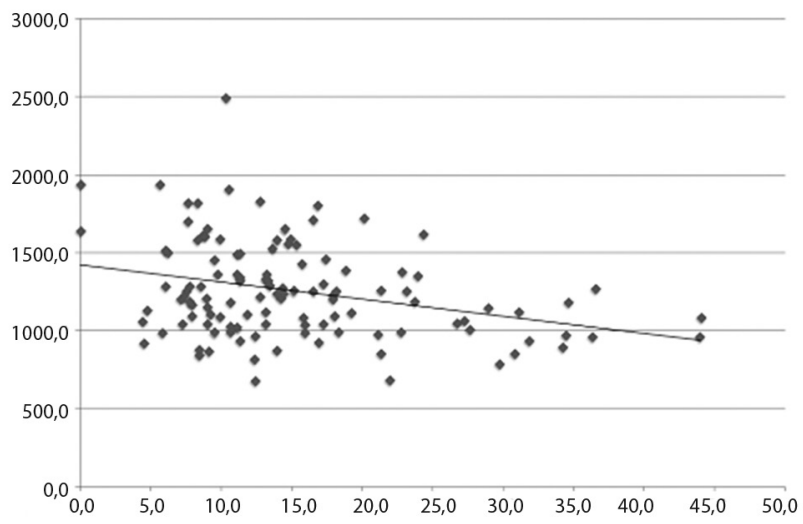

Rysunek 2. Poziom przedsiębiorczości w gminie w zależności od odległości od ośrodka gospodarczego

Źródło: obliczenia własne.

Współczynnik korelacji między zmienną x (odległością od ośrodka gospodarczego) a zmienną y (wskaźnikiem przedsiębiorczości) wynosi-0,31. Wskazuje to na niską, ale wyraźną zależność między badanymi cechami.

Weryfikacja hipotezy potwierdza, że wzrost odległości danej gminy wiejskiej od ośrodka gospodarczego powoduje spadek poziomu przedsiębiorczości, czyli mniejszą liczbę przedsiębiorstw w przeliczeniu na 10 tys. mieszkańców w wieku produkcyjnym.

\section{Podsumowanie}

Badania przeprowadzone na podstawie materiału statystycznego dotyczącego gmin wiejskich i miejsko-wiejskich województwa śląskiego wykazały, że występuje statystycznie istotna zależność pomiędzy poziomem przedsiębiorczości w badanych jednostkach terytorialnych a ich oddaleniem od głównego ośrodka gospodarczego. Wraz z odległością zmniejsza się liczba podmiotów gospodarczych, co wskazuje na powiązanie działalności na obszarach wiejskich z funk- 
cjami lokalnymi. Odległość od ośrodków gospodarczych jest jedną z wielu czynników determinujących poziomu przedsiębiorczości. Oprócz tego wskaźnika występuje m.in. potencjał inwestycyjny, infrastruktura, poziom bezrobocia czy kapitał ludzki.

Uzyskane w trakcie analizy wyniki wyraźnie wskazują, że rozwój obszarów wiejskich jest ściśle powiązany z rozwojem regionalnym, uwzględnia również obszary miejskie. Ośrodki gospodarcze są kierunkami wzrostu ze względu na koncentrację infrastruktury, ludności, zaplecza organizacyjnego czy niedużą odległość od ważniejszych szlaków komunikacyjnych. W celu uaktywnienia gospodarczego gmin o niskim i bardzo niskim poziomie wskaźnika przedsiębiorczości niezbędny jest rozwój infrastruktury, zapewnienie kontaktów $\mathrm{z}$ ewentualnymi inwestorami. Władze lokalne powinny nieustannie promować działalność gospodarczą na terenie województwa i stwarzać istniejącym firmom dobre warunki dla ich działalności.

\section{Literatura}

Iwańska M., Bieńkowska W., Zróżnicowanie wartości wskaźnika przedsiębiorczości $w$ gminach wiejskich województwa mazowieckiego $w$ ukladzie przestrzennym, Acta Scientiarum Polonorum. Oeconomia 9 (3), SGGW, Warszawa 2010.

Makarski S., Przedsiębiorczość w agrobiznesie, PAN, Warszawa 2000.

Oktaba W., Elementy statystyki matematycznej o metodyka doświadczalnictwa, Wydawnictwo Akademii Rolniczej w Lublinie, Lublin1980.

Pałasz L., Aktywność samorząów gmin w rozwoju obszarów wiejskich, Materiały VI Kongresu SERiA, z. 1. Rzeszów 1999.

Rada Ministrów, Przedsiębiorczość - rozwój - praca. Strategia gospodarcza rzadu, Warszawa 2002.

Schumpeter J., Teoria rozwoju gospodarczego, PWN, Warszawa 1960.

Źródła internetowe

www.mapa.pf.pl

www.geo.stat.pl

www.stat.gov.pl 


\title{
SPATIAL DIVERSIFICATION OF THE ENTREPRENEURSHIP INDICATOR VALUE IN THE RURAL AREAS OF THE ŚLĄS PROVINCE
}

\begin{abstract}
The article presents results of the research in relations between Śląsk rural communes' entrepreneurship indicator and their distance to the main provincial economic centers. For the needs were chosen as Śląsk main economic centers are county cities: Będzin, Bielsko-Biała, Bieruń, Cieszyn, Częstochowa, Gliwice, Kłobuck, Lubliniec, Mikołów, Myszków, Pszczyna, Racibórz, Rybnik, Tarnowskie Góry, Wodzisław Śląski, Zawiercie, Żywiec. The entrepreneurship indicator was resented as a number of registered in the REGON system for 10 thousand inhabitants in the production age. The distance between them and rural areas were calculated as shortest road distance. A statistically significant dependency was found between the of entrepreneurship indicator and the distance from the economic centre.
\end{abstract}

Translated by Damian Dunajko, Izabela Klepacka-Dunajko

Keywords: rural areas, entrepreneurship, distance, entrepreneurship indicator, spatial configuration, Śląsk Province

JEL codes: R11, R12 
